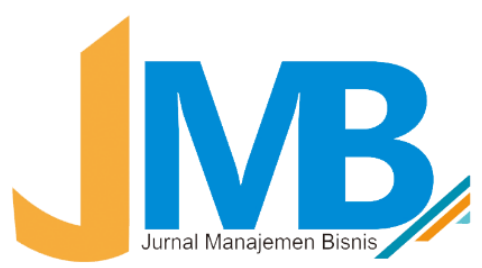

\title{
Financial Literacy: An Essential In Small Medium Entreprises (SMEs) Performance Novita Ratna Satiti
}

University of Muhammadiyah Malang, satiti@umm.ac.id, Indonesia $^{1}$

Received:01-11-2020 | Revision: 05-11-2020 | Accepted:24-11-2020

To cite this document:

Novita Ratna Satiti, (2020) "Financial Literacy: An Essential In Small Medium Entreprises (SMEs) Performance”, Manajemen Bisnis, Vol. 10, No. 02, pp.51-61, https://doi: 10.22219/jmb.v10i2.14825

\begin{abstract}
This study aims to examining the effect of financial literacy on the performance of Small and Medium Enterprises (SMEs) in Malang. This explanatory study was conducted in Sukun District, Malang City. The population was SMEs that located in Sukun District, Malang City which were selected using proportionate stratified random sampling with the total number of 220 samples. The study used descriptive quantitative design with primary data as the data source. The data was analyzed using Smart Partial Least Square (PLS) 3.3 Version with hypothesis tested using Bootstrap. The results of this study indicate that: 1) the financial literacy of the SMEs in Sukun District, Malang City was at a good literacy level which is Sufficient Literate; 2) the Small and Medium Enterprises in Sukun District has a good level of business performance; and Analysis of Smart PLS shows that financial literacy has a positive and significant effect on the performance of Small and Medium Enterprises in Sukun District, Malang. Therefore, financial literacy of the business owner has an important role in business performance. financial literacy can help business actors to gain adequate financial knowledge and capabilities in preparing their business financial strategies and improving their business performance
\end{abstract}

Keywords: Financial Literacy, Financial Performance, SMEs

\section{INTRODUCTION}

The performance of SMEs is crucial to improve business and business competitiveness. When SMEs have a good performance, they could compete with larger companies. In general, the performance of SMEs is often hampered due to various problems, such as inadequate human resource, financing, marketing, technology, competition, and financial problems.

The performance of SMEs is influenced by two factors; internal factors and external factors. The internal factors include aspects of human resources, production and operations, marketing, and finance, while the external factors include aspects of government policies and related institutions that can affect the performance improvement of SMEs. Based on a survey conducted by the Financial Services Authority (OJK), the understanding of financial literacy among Indonesian

\footnotetext{
${ }^{1}$ satiti@umm.ac.id
} 
entrepreneurs is only $27.7 \%$. OJK also claimed that business actors in Indonesia have low level of financial literacy.

A low understanding about financial literacy among the SMEs could affect their business performance, resulting in them less capable of managing finances and making business decisions. It is supported by a research by Lusardi and Tufano (2009), which states that financial literacy can help business actors to gain adequate financial knowledge and capabilities in preparing their business financial strategies and improving their business performance. Financial literacy is an important part of improving company performance. SME owners with good financial knowledge and management can help making financial decisions for their current and future business.

Financial literacy can affect someone's way of thinking about the company's financial condition and strategic financial decision making, thus business owners can carry out financial management properly. The ability to manage good finances is needed by SME actors to improve their business performance. This idea was supported by Aribawa (2016) who argued that financial literacy is needed to improve business performance so that the managed businesses can develop properly.

Bonita et.al. (2018) state that financial literacy is necessary to improve business performance so that it has a good impact on business development. SME actors with a good understanding of financial literacy are able to make the right financial decisions so that they avoid financial problems and can improve their business competitiveness. The higher the level of understanding of the financial literacy among the MSME actors, it can affect the performance of the SMEs. A good understanding of financial literacy can help SME actors to improve the management of their business performance and to use their financial literacy understanding skills for decision making (Rahayu, 2017).

There are several problems faced by SMEs today: most SME actors or business owners do not know and do not understand well about good financial management (Bonita et al. 2018). Many SME actors do not pay enough attention to the procedures for managing their business finances and rarely make savings, investments, and insure some of their assets. Based on the previous description regarding the constraints or problems faced by SMEs one of which is related to the knowledge of financial aspects. As can be seen from the phenomena that exist in SMEs in Malang City, the financial sector becomes the main concern among the SME actors. Based on a survey conducted by OJK in 2016, the financial literacy index in Malang is relatively low, which is only $33.9 \%$.

This fact encourages the researcher to conduct a study on several SMEs in Malang City related to their financial literacy on business performance, specifically in Sukun District as they have the highest number of SMEs compared to other sub-districts in Malang City. SMEs Sukun District was chosen because the SMEs has the potential to become one of the best SMEs compared to other SMEs in Malang City. In addition, the SMEs of Sukun District becomes one of the SMEs which represents SMEs branding in Malang City level.

Malang City has a large number of SMEs and it always increases every year. The total number of SMEs in Malang City in 2018 was 101,776 units (www.bpsmalang.com). Based on the description earlier, it can be concluded that the main problem faced by SMEs relates to financial literacy. Thus, it inspires the researcher to conduct a study on SMEs in Malang City entitled "Financial Literacy: An Essential In Small Medium Entreprises (SMEs) Performance. 


\section{LITERATURE REVIEW}

According to the Financial Services Authority (OJK) (2017), the definition of financial literacy is knowledge, beliefs, and skills that influence attitudes and behavior to improve the quality of decision making and financial management to achieve prosperity. According to the Financial Services Authority (OJK) (2018), the level of Indonesian people's literacy is divided into four parts: Well literate, Sufficient literate, Less literate, and Not literate. The measurement of financial literacy can be measured using several indicators. According to Chen and Volpe, there are four indicators of financial literacy: General Knowledge of Finances, Savings and Loans, Insurance, and Investment.

Financial literacy is not only related to financial knowledge, but also the individual's ability to manage and make financial decisions effectively and efficiently for the benefit of their future. Business actors who have a high level of financial literacy will be able to manage their business finances well, and be able to access financial resources so that they can maintain the sustainability of their business (Puspitaningtyas, 2017). The purpose of financial literacy is so that the income earned is not only spent on unnecessary goods and services, but also for investments that are more productive and bring great benefits for the future. Financial literacy has an important role in business not only for business actors but also for financial institutions. Business actors who initially save money in their cupboard, finally are willing to save their money in a bank after knowing and understanding about the products of the financial service industry, so it is also beneficial for financial institutions because one of its products is in demand by business actors.

Company performance is a complete display of the state of the company for a certain period of time as a result or achievement that is influenced by the company's operational activities in utilizing its resources (Srimindarti, 2004). There are several factors that affect the SME's performance, including: a) internal factors, which consist of human resource, financial, marketing and operational, and; b) external factors, which consist of information related to market conditions, social, economic and cultural conditions in the environment around SMEs, economic policies occurring in the country, and availability of raw materials from suppliers (Purwaningsih \& Kusuma, 2015).

According to Munizu (2010), the performance indicators of SMEs are as follows: 1) Sales growth rate, 2) Increased capital or financial growth rates, 3) Labor growth rates, 4) Broad market growth rates, and 5) Profit growth rates.

\section{RESEARCH METHOD}

This explanatory study was conducted in Sukun District, Malang City. The population was the SMEs located in Sukun District, Malang City which were selected using proportionate statisfied random sampling with the total number of 220 samples from 1.100 units business population that divided in three areas which are; trading sector, services sector, and industrial sector. Determination of the sample using Roscoe's theory regarding the suggested sample size in a feasible study that is between 30 and 500 samples (Saidani, Rachman et al, 2013). From that formulation we had 220 samples in each areas: 120 samples from trading sector, 60 samples from services sector, and 40 samples from industrial sector. 
This research was an explanatory research. The study used descriptive quantitative data with primary data as the data source. The data was analyzed using Smart PLS 3.3 Version with hypothesis tested using Bootstrap. The analysis process begins with testing the outer model which includes testing the validity and reliability, and then performing the classical assumption test before performing regression analysis, namely the normality test and heteroscedasticity test. After that, PLS Structural Model Analysis (inner model) is performed, and ended by testing the hypothesis. If the hypothesis testing on the outer model is significant, then it indicates that the indicator can be used as an instrument to measure latent variables. Meanwhile, if the test on the inner model is significant, it means that there is a significant effect of the latent variable on the other latent variables.

\section{RESULT AND DISCUSSION}

Based on the analysis of the respondent's questionnaire, it can be concluded that the respondents of SMEs in Sukun District who have major businesses are at the age of 41-45, followed by 36-40 which is the productive age, where someone wants to generate income by entrepreneurship, not just relying on one job only. Based on the gender, SMEs in Sukun District are dominated by men, while women are less interested and less enthusiastic in learning things related to business and entrepreneurship. It is indicates that men have better financial literacy level than women.

Based on the business sectors that are most in demand by business actors, it shows that the trade sector is the highest, because the trade sector has a very good opportunity to open a new business, and the trading sector has a better literacy level compared to the services and industrial sectors, and this will have an impact on improving business performance. Meanwhile, the duration of the business that has been carried out shows, that the length of time the business has been operating is dominated by 1-5 years wich are categorized as a new business. The length of time a business operates can affect someone's knowledge in managing a business, based on their experience including in the financial sector. It is indicates that the longer the business operates, the better the understanding of financial literacy will be.

Based on the respondents' data analysis, it is can be concluded that the start-up capital for SMEs does not require a huge amount of money because it is still starting a new business and the capital required is in accordance with the needs from the start of the business. On the other hand, the capital of SMEs currently increases compared to the initial capital. Capital has an important role in improving business performance and maintaining business activities, because business capital is used for business operations.

The Range of Respondents' Answer related to Financial Literacy shows that the average calculation of the level of financial literacy among SMEs owner in Sukun District, Malang City is relatively good. It can be seen from the average score in good understanding of financial literation. Therefore, based on the average results of the calculations, the level of financial literacy among SME actors in Sukun District is in the sufficient literate category. The performance of SMEs in Sukun District, Malang City is categorized good as it can be seen from the average score form indicators of good business performance. From the data, it can be concluded that the SME actors in Sukun District have already had good achievements or results in their businesses. 


\section{Partial Least Square Analysis (Outer Model Evaluation)}

The outer model evaluation test includes validity and reliability tests which are described as follows:

a. Validity Test

The convergent validity test for reflective indicators using the Smart PLS 3.3 program can be seen from the loading factor value for each construct indicator in Figure 1. Due to the current study is explanatory, the criteria for passing the validity test are that the loading factor value between 0.6-0.7 is acceptable and the Average Variance Extracted (AVE) value must be more than 0.5 (Ghozali, 2015: 74).

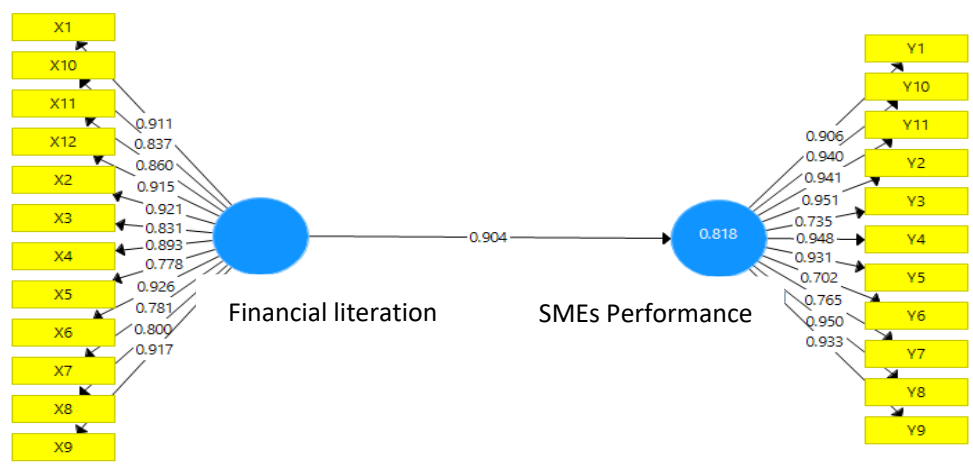

Source: PLS Data Processed Output

\section{Figure 1. Outer Model Calculation Results}

Tables 1 and 2 show that the Outer Model of each item of financial literacy and SME performance has a correlation greater than 0.6 and all are valid.

Table 1. Outer Loading Financial Literacy

\begin{tabular}{ccc}
\hline Variable & Financial Literacy & Status \\
\hline X1 & 0.911 & Valid \\
X2 & 0.921 & Valid \\
X3 & 0.831 & Valid \\
X4 & 0.893 & Valid \\
X5 & 0.778 & Valid \\
X6 & 0.926 & Valid \\
X7 & 0.781 & Valid \\
X8 & 0.800 & Valid \\
X9 & 0.917 & Valid \\
X10 & 0.837 & Valid \\
X11 & 0.860 & Valid \\
X12 & 0.915 & Valid \\
\hline Source: PLS Data Processed Output
\end{tabular}


Table 2. Outer Loading SME Performance

\begin{tabular}{ccc}
\hline Variable & $\begin{array}{c}\text { SME } \\
\text { Performance }\end{array}$ & Status \\
\hline X1 & 0.906 & Valid \\
X2 & 0.735 & Valid \\
X3 & 0.948 & Valid \\
X4 & 0.931 & Valid \\
$\mathbf{X 5}$ & 0.702 & Valid \\
X6 & 0.765 & Valid \\
X7 & 0.950 & Valid \\
X8 & 0.933 & Valid \\
X9 & 0.906 & Valid \\
X10 & 0.940 & Valid \\
X11 & 0.941 & Valid \\
X12 & 0.951 & Valid \\
\hline \multicolumn{2}{r}{ Source: PLS Data Processed Output }
\end{tabular}

b. Reliability Test

This measurement model was done by using a construct reliability test. The reliability test was carried out to prove the accuracy, consistency, and accuracy of the instruments in measuring constructs. Because the current study is explanatory, the criteria for assessing construct reliability in this study are the Composite Reliability value of 0.6-0.7 is acceptable and the Average Variance Extracted (AVE) value must be more than 0.5 (Ghozali, 2015: 75).

Table 3. Reliability of the Construct

\begin{tabular}{ccccc}
\hline Variable & Cronbach's Alpha & rho_A & $\begin{array}{c}\text { Aomposite } \\
\text { Reliability }\end{array}$ & $\begin{array}{c}\text { Average } \\
\text { Variance } \\
\text { Extracted } \\
\text { (AVE) }\end{array}$ \\
\hline SME Performance & 0.970 & 0.973 & 0.973 & 0.749 \\
Financial Literacy & 0.971 & 0.972 & 0.976 & 0.786 \\
\hline
\end{tabular}

Source: PLS Data Processed Output

Based on Table 3, Composite reliability in the financial literacy and performance tables of SMEs has a composite reliability value above 0.7 and an AVE value above 0.5 so that the indicators of each variable are said to be reliable because they have a good reliability value.

\section{Classic Assumption Test}

a. Normality Test

Normality test is carried out using graphs by looking at the distribution of data on the Normal P-Plot of Regression Standardized Residuals. The basis for the decision making is that if the point spreads around the diagonal line and follows the direction of the diagonal line, then it shows a normal distribution pattern. The normality test in this study used the Kolmogorov-Smirnov test. The significance value of the results from the Kolmogrorov-Smirnov test exceeds the significance level of 0.05 , therefore the residual data is normally distributed. 
Table 4. Data Normality Test Results

One-Sample Kolmogorov-Smirnov Test

\begin{tabular}{|c|c|c|}
\hline & & $\begin{array}{l}\text { Unstandardized } \\
\text { Residual }\end{array}$ \\
\hline \multicolumn{2}{|c|}{$\mathrm{N}$} & 220 \\
\hline \multirow{2}{*}{ Normal Parameters ${ }^{\mathrm{a}, \mathrm{b}}$} & Mean & .0000000 \\
\hline & Std. Deviation & 2.89658822 \\
\hline \multirow[t]{3}{*}{ Most Extreme Differences } & Absolute & .049 \\
\hline & Positive & .028 \\
\hline & Negative & -.049 \\
\hline Test Statistic & & .049 \\
\hline Asymp. Sig. (2-tailed) & & $200^{\mathrm{cd} d}$ \\
\hline
\end{tabular}

a. Test distribution is Normal.

b. Calculated from data.

c. Lilliefors Significance Correction.

d. This is a lower bound of the true significance.

Source:SPSS Data Processed Output.

Source: SPSS Data Processed Output.

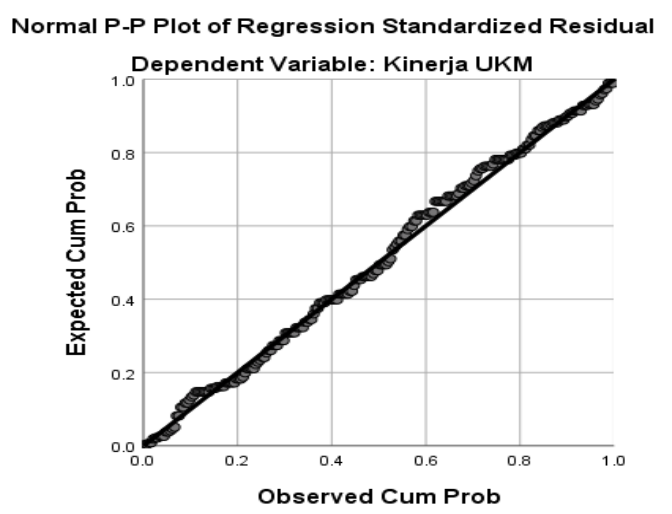

Figure 2. Normal P-Plot of Regression Chart

Based on Table 4, the results of the normality test using the Kolmogrov-Smirnov method obtained a significance result of 0.200 , where the value is greater than the significance level of 0.05 . Thus, it can be concluded that the data in this study were normally distributed. By using the graph method in Figure 2, it can be seen on the $P$ Plot graph that the dots follow the diagonal lines, which means that the current study has met the normality assumption.

b. Heteroscedasticity Test

The current study used the heteroscedasticity test with the Glejser test with significance greater than $5 \%$ or 0.05 . 


\begin{tabular}{|c|c|c|c|c|c|c|}
\hline & \multirow[b]{3}{*}{ Model } & \multicolumn{2}{|c|}{ Coefficients $\mathrm{s}^{\mathrm{a}}$} & \multirow[b]{2}{*}{$\begin{array}{l}\text { Standardized } \\
\text { Coefficients }\end{array}$} & \multirow[b]{3}{*}{$\mathrm{T}$} & \multirow[b]{3}{*}{ Sig. } \\
\hline & & \multicolumn{2}{|c|}{$\begin{array}{l}\text { Unstandardized } \\
\text { Coefficients }\end{array}$} & & & \\
\hline & & B & Std. Error & Beta & & \\
\hline \multirow[t]{2}{*}{1} & (Constant) & 2.541 & 1.406 & & 1.808 & .072 \\
\hline & Financial Literacy & -.004 & .030 & -.009 & -.126 & .900 \\
\hline
\end{tabular}

Source: SPSS Data Processed Output.

Based on Table 5, the results of the heteroscedasticity test using the Glejser test show that the financial literacy variable $(X)$ produces a significance value of 0.900 , and this value is greater than the significance level of 0.05 . Therefore, it can be concluded that this study does not occur heteroscedasticity problems and the research data is homoscedasticity.

\section{Partial Least Square Analysis (Inner Model Evaluation)}

Structural Model is a model that connects latent variables, namely financial literacy on the performance of SMEs. The value of R-Square can be used to explain the effect of latent variables, namely Financial Literacy, on endogenous variables, namely the performance of SMEs whether they have a strong, moderate or weak influence. RSquare of 0.75 indicates a strong model, 0.50 a moderate model (moderate) and 0.25 a weak model (Ghozali: 2015).

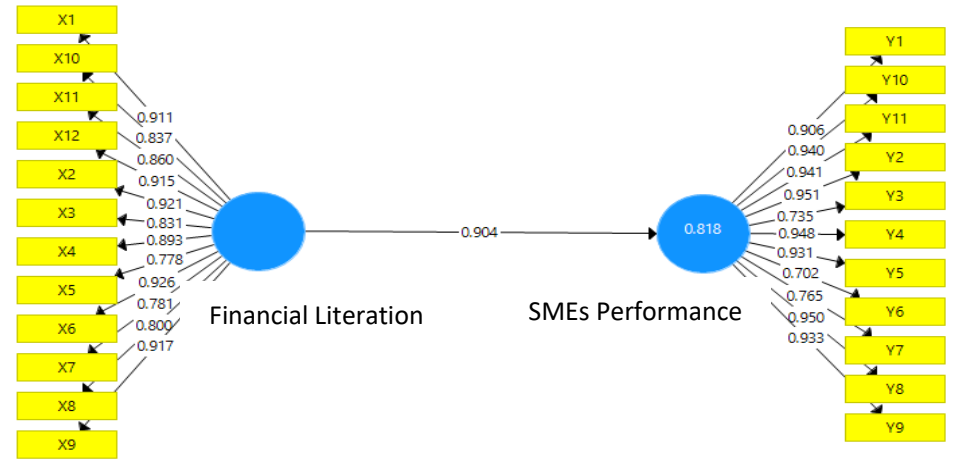

Source: PLS Data Processed Output.

Figure 3. Inner Model Evaluation Results

Based on Figure 3, the calculation results of the inner model above can be explained from the coefficient of determination which shows the magnitude of the influence of the financial literacy variable on the performance of SMEs which are presented in Table 6.

Table 6. Determination Coefficient (R-Square)

\begin{tabular}{ccc}
\hline Indicator & R-Square & $\begin{array}{c}\text { R Square } \\
\text { Adjusted }\end{array}$ \\
\hline SME Performance & 0.818 & 0.817 \\
\hline \multicolumn{2}{c}{ Source: PLS Data Processed Output. }
\end{tabular}


Table 6 shows the result of R-Square determination value, namely financial literacy $(\mathrm{X})$ on SME performance (Y) giving an R-Square value of 0.818 , indicating that financial literacy on SME performance has a strong effect, where R-Square is more than 0.75

\section{Hypothesis Testing}

Hypothesis testing is used to determine the effect of the independent variable, namely financial literacy $(\mathrm{X})$, on the dependent variable, namely the performance of SMEs (Y). The requirement to pass the hypothesis test to be significant is that the $\mathrm{t}-$ count is greater than ( $5 \%$ significant t-table) 1.96 or the p-value is less than 0.05 (Ghozali, 2015: 78).

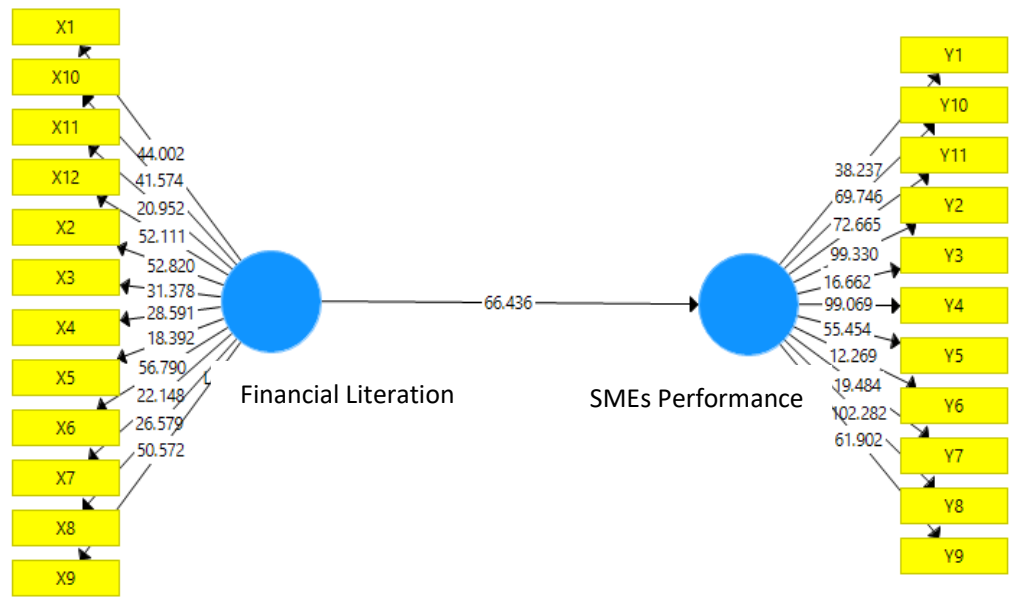

Source: PLS Data Processed Output.

Figure 4. Bootstrapping Calculation Results

Table 7 shows the results of the bootstrapping analysis which illustrates the effect of the financial literacy variable $(\mathrm{X})$ on the performance of SMEs, which is significant with the results on the significance of the t-table value $>1.96$ and the p-value less than 0.05 . Based on the results, the inner model relationship between the financial literacy variable $(\mathrm{X})$ and the SME performance variable $(\mathrm{Y})$ shows a positive and significant effect, so the hypothesis is accepted.

Table 7. Inner Model Path Coefficient

\begin{tabular}{lccccc}
\hline $\begin{array}{c}\text { Relationship } \\
\text { Among }\end{array}$ & $\begin{array}{c}\text { Original } \\
\text { Sample } \\
(\mathbf{O})\end{array}$ & $\begin{array}{c}\text { Sample Mean } \\
(\mathbf{M})\end{array}$ & $\begin{array}{c}\text { Standard } \\
\text { Deviation } \\
\text { (STDEV) }\end{array}$ & $\begin{array}{c}\text { T Statistics } \\
(\mid \mathbf{O} / \text { STDEV } \mid)\end{array}$ & P Values \\
\hline $\begin{array}{l}\text { Financial } \\
\text { Literacy -> }\end{array}$ & 0.904 & 0.904 & 0.014 & 66.436 & 0.000 \\
$\begin{array}{l}\text { SME } \\
\text { Performance }\end{array}$ & & & & & \\
\hline
\end{tabular}

Source: PLS Data Processed Output.

\section{CONCLUSION}

SMEs in Malang City has proven to have a good level of financial literacy. It is based on the responses of 220 respondents who acknowledged that they already understand about recording income and expenditure of business funds, the decisions in 
business, interest rates when making deposits and loans at a bank, insurance as a protection against the occurrence of business risks and the types of insurance products used, and the risks when investing.

SMEs in Malang City has a good level of business performance. It is proven by the growth of businesses they manage in terms of sales, capital, operating profits, labor, and a wider market reach. There are only a few SMEs that have not experienced growth due to not optimal performance of the SME actors in Sukun District.

Financial literacy has a positive and significant effect on the performance of SMEs so that the hypothesis is accepted, which means that financial literacy affects the performance of SMEs in Sukun District, Malang City. In other words, the better the understanding of financial literacy among business actors, the higher the performance of SMEs in Sukun District.

It is necessary for SME actors to always improve their understanding and skills regarding financial literacy to maintain and improve the SME's performance. Thus, future researchers are suggested to conduct a research in different places to discover differences in financial literacy and SMEs' performance, especially in places that have not been studied

\section{REFERENCES}

Anggraeni, B. D. 2015. Pengaruh Tingkat Literasi Keuangan Pemilik Usaha Terhadap Pengelolaan Keuangan. Studi Kasus: UMKM Depok. Jurnal Vokasi Indonesia. Vol 3 No.1. 22-30.

Aribawa, D. 2016. Pengaruh Literasi Keuangan Terhadap Kinerja dan Keberlangsungan Usaha UMKM di Jawa Tengah. Jurnal Siasat Bisnis Vol. 20 No.1.1. Hal 1-13.

Bonita, Ayu Putu Aratza, dan Setiawan, Nyoman Djinar. 2018. Analisis Determinasi Tingkat Literasi Keuangan Pedagangan Tradisional di Kota Denpasar. E-Jurnal Ekonomi Pembangunan Universitas Udayana. Vol 7 No,2 Hal 354-380.

Dahmen, P., and Rodriguez, E. (2014)." Financial Literacy and the success of Small Businesses: An Observation from a Small.

Devi, Bella Cynthia, Hoyyi, Abduh dan Mukid, Moch. Abdul. 2015. Analisis faktorfaktor yang mempengaruhi keputusan pembelian dan kepuasan konsumen pada layanan internet speedy di Kota Semarang, menggunakan Partial Least Square (PLS). Jurnal Gaussian, Vol 4, No 3, Halaman 485-495

Dinas Koperasi dan Usaha Kecil Menengah Kota Malang. 2018. Pemetaan data UKM Kota Malang.

Fatoti, O. 2014. The Financial Literacy Of Micro Enterpreneurs In South Africa Journal Of Business Management, Vol 40 (2), 151-158.

Ghozali, Imam. 2016. Aplikasi analisis multivariate dengan progam IBM SPSS 20. Cetakan ke 8. Semarang. Badan Penerbit Universitas Diponegoro.

Indrawan, Rully, dan Yaniawati, Poppy. 2014. Metodologi Penelitian Kuantitatif, Kualitatif, dan Campuran untuk Manajemen, Pembangunan dan Pendidikan, Cetakan Satu. Bandung. PT Refika Aditama.

Jati, Hironnymus. 2017. Pengetahuan Manajemen Bisnis, Literasi Keuangan dan Kinerja UMK Ekonomi Kreatif di Kabupaten Flores Timur. Seminar nasional 
Riset Inovatif. ISBN:978-602-6428-11-0. Jurusan Manajemen Fakultas Ekonomi dan Bisnis Universitas Nusa Cendana Kupang.

Jati, Hironnymus, Dominikus Farendes, dan Indri Astutu 2017. Enpowement MSE Creative Economy Through Innovation Progam To Increase Revenue Golden Community : Study in The Regency East Flores. International Journal of Management and Administrative Science (IJMAS), (ISSN:2225-7225), Vol 4, N0.12 (27-44). Pakistan Society of Business and Management Research.

Kustia, Putri Hanifah (2019). Analisis pengaruh literasi dan inklusi keuangan terhadap kinerja pelaku usaha kecil dan menengah (ukm) (studi kasus pelaku usaha kecil dan menengah kota malang). Jurnal Ilmiah. Jurusan Manajemen Fakultas Ekonomi dan Bisnis Universitas Brawijawa.

Kapoor, Dlablay, Hughes, Hart. 2016. Focus On Personal Finance. Fifth edition. McGraw-Hill education. New York.

Kurniawan, A. W., dan Z. Puspitaningtyas. 2016. Metode Penelitian Kuantitatif. Yogyakarta: Pandiva Buku.

Lusardi, A., and Mitchell, O. S. (2011): Financial Literacy and Planning; Implications for Retirement Well being. National Bureau of Economic Research.

Marieta, Lonela, Andrei, Micaela. 2013. Performance Indicators Used By SMEs in Romania.

Martono, Manang 2010. Metode Penelitian Kuantitatif. Cetakan pertama. Jakarta. PT Raja Grafindo Persada.

Munawir, S. 2000. Analisis Laporan Keuangan. Edisi Keempat. Yogyakarta: PT Liberty.

Munizu, Musran. 2010. Pengaruh Faktor-Faktor Eksternal dan Internal Terhadap Kinerja Usaha Mikro dan Kecil (UMK) di Sulawesi Selatan. Jurnal Manajemen dan Kewirausahaan. Vol 12. No.1 Maret 2010 33-41

Otoritas Jasa Keuangan. 2016. Survei Nasional Literasi Keuangan. (https://www.ojk.go.id) diakses pada 1 Desember 2019 pada pukul 20.30 WIB.

Otoritas Jasa Keuangan. 2016. Pengertian Literasi Keuangan. (https://www.ojk.go.id) diakses pada 1 Desember 2019 pada pukul 20.30 WIB.

Patrick, C (2015). The Effect of Financial Literacy on Performance of Small and Medium Enterpises in Trans Nzonia Country By: Cherugong Patrick a Research Project Submitted in Partial Fulfillment of The Requirements for the Degree of Master of Business Administration, Scho, (November).

Rahayu, A. Y., dan Musdholifah. 2017. Pengaruh Literasi Keuangan Terhadap Kinerja dan Keberlanjutan UMKM di Kota Surabaya. Jurnal Ilmu Manajemen. Vol 5 Nomor 3.

Sedarmayanti. 2008. Sumber Daya Manusia dan Produktifitas Kerja. Bandung CV Mandar Maju.

Sugiono. 2015. Metode Penelitian dan Pengembangan (research and development/R\&D). Bandung. Alfabeta.

Website Otoritas Jasa Keuangan. 2016. Survei Tingkat Literasi Keuangan. https://sikapiuangmu.ojk.go.id/FrontEnd/images/Document/buku\%20statistik_201 6.pdf diakses pada 1 Desember 2019 pada pukul 20.30 WIB.

World Bank. (2016). Trends in the Objectives of National Financial Capability Strategies (p. 9). World Bank. 